\title{
C-band variants of telocentric chromosomes in swine : evidence and inheritance studies (1)
}

\author{
M. SẂWITONŚSI *, R. FRIES and G. STRANZINGER ** \\ Swiss Federal Institute of Technology Zürich, Institute of Animal Production, \\ Breeding Section, $\mathrm{CH}-8092$ Zürich
}

\begin{abstract}
Summary
Using Q- and C-band sequential staining, variability in the size of C-bands was found in several pig chromosome pairs. Distinct variability in the size of C-bands was found in pairs 16, 17, and 18, and suspected in pairs 13 and 15. For pairs 16, 17, and 18, inheritance studies in 11 families were carried out. It was found that C-band variants were stable within individuals and were inherited according to the Mendelian principle. The phenomenon of this $\mathrm{C}$-band polymorphism in relation to its importance and application for cytogenetic investigations and animal breeding is discussed.
\end{abstract}

Key words : Swine, chromosomes, C-bands, polymorphism.

\section{Résumé}

Les variants des bandes $C$ de chromosomes télocentriques chez le porc : description et mode de transmission

Grâce à l'utilisation des méthodes de coloration séquentielle des bandes $\mathrm{Q}$ et $\mathrm{C}$, on a pu mettre en évidence une variabilité de taille des bandes $\mathrm{C}$ de différentes paires de chromosomes du porc. De nettes variations dans la taille des bandes C ont été observées au niveau des paires chromosomiques 16,17 et 18 , et soupçonnées au niveau des paires 13 et 15. Une analyse génétique des variations des bandes $C$ des paires 16,17 et 18 a été entreprise dans 11 familles. Il apparaît que les variants observés sont stables chez les individus, et se transmettent selon un mode mendelien. L'article discute l'intérêt et les applications de ce polymorphisme des bandes $C$ en cytogénétique et sélection animale.

Mots clés : Porcins, cytogénétique, bandes C, polymorphisme.

(1) This work was supported by the Schweizerische Arbeitsgemeinschaft für Künstliche Besamung, Brugg and a fellowship of the ETH Zürich.

* Present address : Academy of Agriculture, Department of Genetics and Animal Breeding, Wolyniska 33, 60-637 Poznan. Poland.

** Reprint request : G. Stranziger, Swiss Federal Institute of Technology, Zürich. Institute of Animal Production, Breeding Section, ETH-Zentrum, CH-8092 Zürich. 


\section{Introduction}

In the karyotype of swine it can be demonstrated by the C-banding technique that constitutive heterochromatin occurs in the centromeric regions of all chromosomes and on the long arm of the Y chromosome. As was shown by LiN et al. (1982), there are four types of constitutive heterochromatin in swine according to the proportion of A-T and G-C repetitive sequences. According to the definition of a polymorphism, the variants should be distinct, discontinuous, and inherited.

Variability in C-band size in porcine chromosomes has been described by several authors : Hansen-Melander \& Melander (1974), Christensen \& Smedegárd (1978, 1979), Sysa (1980), GlahN-Luft et al. (1981, 1982), Fries \& Stranzinger (1981), and HANSEN $(1981,1982)$. But only the last three papers applied the Q-band method which is essential for the precise identification of particular chromosomes within the karyotype.

The heritable character of C-band polymorphism has been described in other mammals ; in humans by Phillips (1977), Robinson et al. (1976), and Craig-Holmes et al. (1975), in mice by DEv et al. (1973), and in the rabbit by ŚwITOŃSKI et al. (1982). $\mathrm{C}$-band variants have also been described more generally for many other species including the rat (Yosida \& SAGAI, 1975), blue fox (MäKINEN \& Gustavsson, 1980), and cattle (Popescu \& Boscher, 1975, and Di Berardino et al., 1980).

$\mathrm{C}$-band polymorphism, apart from application in experimental investigations, is expected to have an influence on the phenotype as was shown in humans by JACOBS et al. (1975), SoudeK \& SROKA (1979), RobSON et al. (1981), and ATKIN \& BritoBabPulle (1981).

The aims of the present paper are : (1) description of different C-band size variants of telocentric (1) chromosomes of pigs and (2) inheritance studies of the clearly defined $\mathrm{C}$-band variants for verification of the polymorphism in swine.

\section{Materials and methods}

The study was carried out on 96 animals comprising 11 families of the Swiss Landrace breed.

Cytogenetic analyses were based on standard lymphocyte cultures (FrIEs \& STRANZINGER, 1982) using Ham's F 10 medium complemented with fetal calf serum, L-glutamine, and pokeweed as the most suitable mitogen.

For all animals sequential stained karyotypes, according to the Q-band method of CAspersson et al. (1969) and C-band method of SumNer (1972), were obtained. The major steps for the C-band procedure were : 1 hour in $0.2 \mathrm{~N} \mathrm{HCI}$ at room temperature, 1 minute in 5 p. $100 \mathrm{Ba}(\mathrm{OH})_{2}$ at $50{ }^{\circ} \mathrm{C}$, and 20 minutes in SSC $0.30 \mathrm{M}$

(1) Following the morphological nomenclature of the Reading Conference (1976). 
$(17.530 \mathrm{~g} / \mathrm{l}) \mathrm{NaCl}, 0.03 \mathrm{M}(18.82 \mathrm{~g} / \mathrm{l})$ sodium citrate at $60^{\circ} \mathrm{C}$. For each animal 2 to 6 sequentially stained metaphases were analysed. Using chromosome No. 14 as a standard background (see Results) a minimum of heterochromatic material was scored as (-), while the presence of a large heterochromatic area with at least twice the (-) variant material was scored as (+). No further measurements on the $\mathrm{C}$-band areas were made at this stage since the priority was to analyze the polymorphism in a general sense.

A Zeiss fluorescence microscope with an excitation filter BP 390-440, splitting mirror FT 460, and barrier filter LP 470 was used. Karyotypes were arranged according to the Reading Conference (1976). For the inheritance study the chi-square test was applied.

\section{Results}

The Q-banding technique allowed a precise identification of all chromosomes in the karyotype of the pig. Among the animals studied $\mathrm{C}$-band variants were observed on chromosome pairs $13,15,16,17$, and 18 (fig. 1, 2, and 3). In pairs 16, 17, and 18 differences in $\mathrm{C}$-band size between variants were very large and distinct. In these pairs we found all possible $C$-band variants, which we classified as $(++),(+-)$

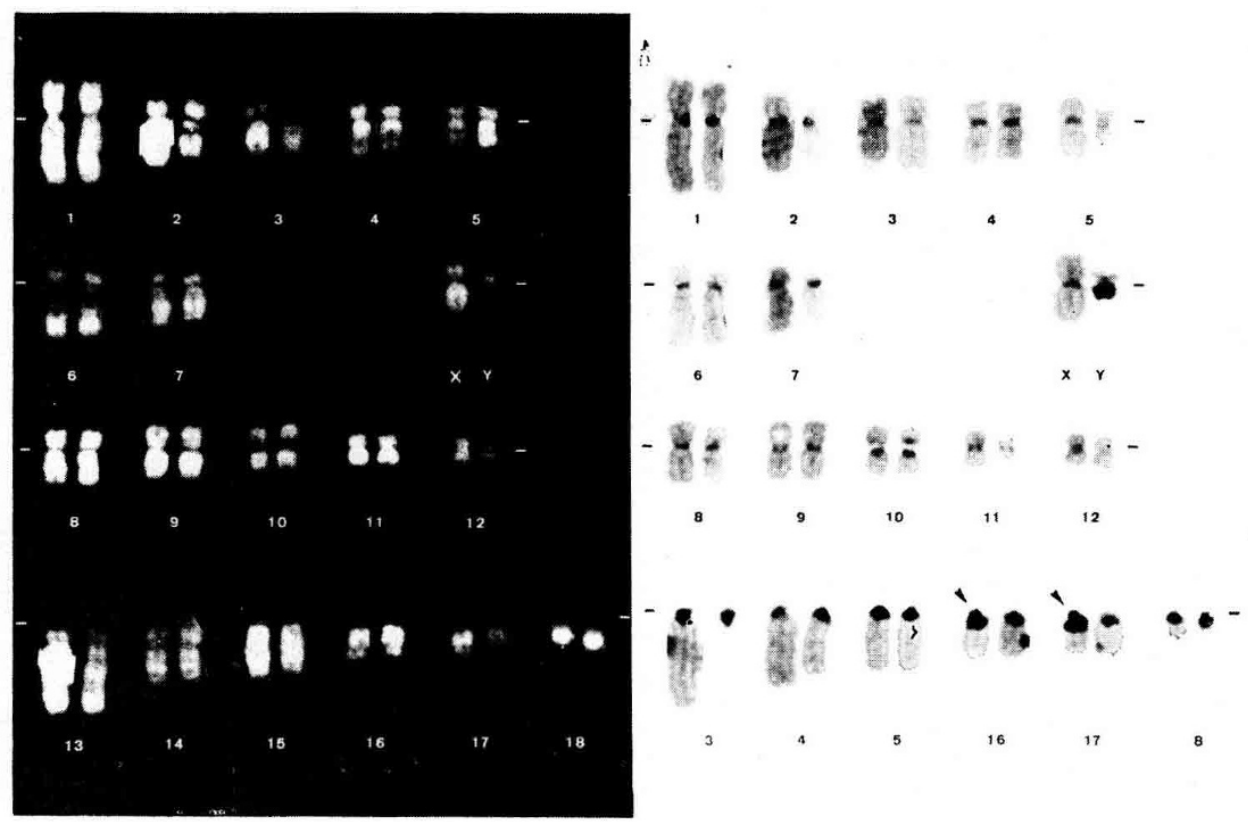

FIG. 1

Sequential $Q$ - and $C$-band stained karyotype of swine. Arrows indicate C-band (+) variant in pairs 16 and 17.

Caryotype de porc coloré en bandes séquentielles $Q$ et $C$. Les flèches indiquent le variant de la bande $C(+)$ des paires 16 et 17. 


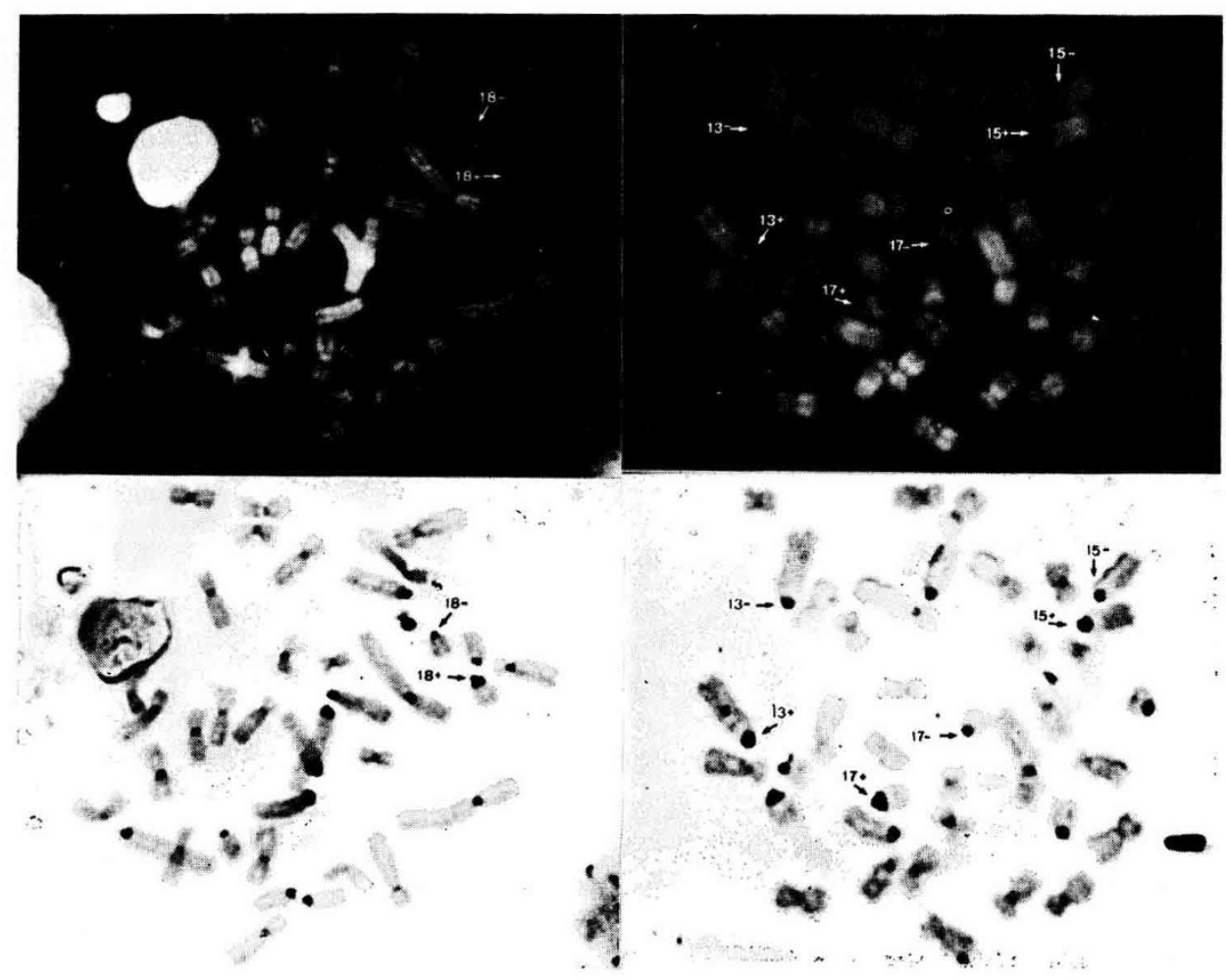

Fig. 2

Sequential $Q$ - and $C$-band stained metaphase, showing $C$-band variants in pair 18. Métaphases colorées en bandes séquentielles $Q$ et $C$ qui montrent des variants de la bande $C$ de la paire 18.

FIg. 3

Sequential $Q$ - and $C$-band stained metaphase, showing $C$-band variants in pairs 13,15 et 17.

Métaphases colorées en bandes séquentielles $Q$ et $C$, montrant des variants de la bande $C$ des paires 13,15 et 17.

and (- -) for both homologues. Within an individual the defined variants for both homologues were constant. However, in pairs 13 and 15, the differences in C-band size were not as distinct as in pairs 16,17 , and 18, and in a few metaphases it was difficult to recognize the difference in the expected $\mathrm{C}$-band variant. But in these pairs all three variants $(++,+-$ and --$)$ were still observed on good preparations even though the size differences were not that distinct. Due to some technical difficulties in preparation or identification the inheritance study was restricted to consideration of pairs 16,17 , and 18 which were classified as (-). In these pairs, C-band variants were very clear and there were no problems in distinguishing between them. As shown in the figures of metaphases from different animals, the differences in size of C-band variants were large, i.e. in fig. 1 the $(+)$ variants in chromosome No. 16 and 17 are 
twice as large as the (-) variants. Chromosome pair 14 shows less variability in the size of the C-band than pairs 13 and 15 if several metaphases of a given animal are compared. The variability observed in the chromosome pair 14 which appears in figure 1 is not characteristic in this respect.

TABLE 1

Familial investigations of C-band variants' inheritance in pigs.

Déterminisme génétique des variants des bandes $C$ du porc : étude de familles.

\begin{tabular}{|c|c|c|c|c|c|c|}
\hline \multirow{2}{*}{$\begin{array}{c}\text { No. } \\
\text { of family }\end{array}$} & \multirow{2}{*}{\multicolumn{2}{|c|}{ Parents }} & \multirow{2}{*}{$\begin{array}{c}\text { Progeny } \\
\text { (1) }\end{array}$} & \multicolumn{3}{|c|}{ Chromosome pair } \\
\hline & & & & 16 & 17 & 18 \\
\hline 1 & A I & $\begin{array}{l}\hat{\alpha} \\
\dot{q}\end{array}$ & $\begin{array}{l}1 \\
8 \\
2\end{array}$ & $\begin{array}{l}-- \\
-- \\
--\end{array}$ & $\begin{array}{l}+- \\
+- \\
++ \\
+-\end{array}$ & $\begin{array}{l}-- \\
-z \\
-- \\
--\end{array}$ \\
\hline 2 & $A_{\text {III }}$ & $\begin{array}{l}\hat{o} \\
\grave{+}\end{array}$ & $\begin{array}{l}3 \\
4 \\
1 \\
\end{array}$ & $\begin{array}{l}-- \\
-- \\
-- \\
--\end{array}$ & $\begin{array}{l}+- \\
+- \\
++ \\
+-\end{array}$ & $\begin{array}{l}-- \\
-- \\
-- \\
--\end{array}$ \\
\hline 3 & A III & $\begin{array}{l}\hat{\delta} \\
\stackrel{q}{q}\end{array}$ & $\begin{array}{l}1 \\
1 \\
1\end{array}$ & $\begin{array}{l}-- \\
+- \\
+- \\
+-\end{array}$ & $\begin{array}{l}+- \\
-- \\
+- \\
--\end{array}$ & $\begin{array}{l}-- \\
+- \\
+- \\
+-\end{array}$ \\
\hline 4 & A IV & $\begin{array}{l}\hat{\sigma} \\
q\end{array}$ & $\begin{array}{l}2 \\
1 \\
1\end{array}$ & $\begin{array}{l}-- \\
-- \\
--\end{array}$ & $\begin{array}{l}+- \\
+- \\
+- \\
--\end{array}$ & $\begin{array}{l}-- \\
+- \\
+- \\
--\end{array}$ \\
\hline 5 & A V & $\begin{array}{l}\hat{o} \\
\hat{q}\end{array}$ & $\begin{array}{l}1 \\
5 \\
4\end{array}$ & $\begin{array}{l}-- \\
+- \\
+- \\
--\end{array}$ & $\begin{array}{l}+- \\
+- \\
-- \\
--\end{array}$ & $\begin{array}{l}-- \\
-z \\
-- \\
--\end{array}$ \\
\hline 6 & B VI & $\begin{array}{l}\hat{o} \\
q\end{array}$ & $\begin{array}{l}1 \\
1\end{array}$ & $\begin{array}{l}+- \\
-- \\
--\end{array}$ & $\begin{array}{l}+- \\
+- \\
++ \\
+-\end{array}$ & $\begin{array}{l}-- \\
-- \\
--\end{array}$ \\
\hline 7 & B VII & $\begin{array}{l}\hat{\delta} \\
q\end{array}$ & $\begin{array}{l}1 \\
2 \\
1 \\
2 \\
1\end{array}$ & $\begin{array}{l}+- \\
+- \\
++ \\
+- \\
++ \\
+-\end{array}$ & $\begin{array}{l}+- \\
-- \\
-- \\
+- \\
+- \\
--\end{array}$ & $\begin{array}{l}-- \\
-- \\
-- \\
-- \\
--\end{array}$ \\
\hline
\end{tabular}


TABLE 1 (continuation)

\begin{tabular}{|c|c|c|c|c|c|c|}
\hline \multirow{2}{*}{$\begin{array}{c}\text { No. } \\
\text { of family }\end{array}$} & \multirow{2}{*}{\multicolumn{2}{|c|}{ Parents }} & \multirow{2}{*}{$\begin{array}{l}\text { Progeny } \\
\text { (1) }\end{array}$} & \multicolumn{3}{|c|}{ Chromosome pair } \\
\hline & & & & 16 & 17 & 18 \\
\hline 8 & C VIII & $\begin{array}{l}\hat{\delta} \\
\text { Oे }\end{array}$ & $\begin{array}{l}1 \\
6 \\
2\end{array}$ & $\begin{array}{l}+- \\
+- \\
++ \\
+- \\
-\longrightarrow\end{array}$ & $\begin{array}{l}-- \\
-- \\
-- \\
--\end{array}$ & $\begin{array}{l}-- \\
-- \\
-- \\
--\end{array}$ \\
\hline 9 & D VIII & $\begin{array}{l}\hat{o} \\
+\end{array}$ & $\begin{array}{l}5 \\
4\end{array}$ & $\begin{array}{l}-- \\
+- \\
+-\end{array}$ & $\begin{array}{l}-- \\
-- \\
--\end{array}$ & $\begin{array}{l}-- \\
-- \\
--\end{array}$ \\
\hline 10 & E VI & $\begin{array}{l}\hat{\delta} \\
\hat{q}\end{array}$ & $\begin{array}{l}6 \\
2 \\
\end{array}$ & $\begin{array}{l}-- \\
-- \\
--\end{array}$ & $\begin{array}{l}-- \\
+- \\
+-\end{array}$ & $\begin{array}{l}-- \\
-- \\
--\end{array}$ \\
\hline 11 & F IX & $\begin{array}{l}\hat{\delta} \\
\text { Q }\end{array}$ & $\begin{array}{l}4 \\
6\end{array}$ & $\begin{array}{l}-- \\
-- \\
--\end{array}$ & $\begin{array}{l}-- \\
+- \\
+-\end{array}$ & $\begin{array}{l}-- \\
-- \\
--\end{array}$ \\
\hline
\end{tabular}

(1) In progeny, number of animals with described C-band variants is given.

TABle 2

Chi-square test of inherilance study of C-band variants in different types of mating.

Tests du $\chi^{2}$ sur la ségrégation des variants des bandes $C$ dans différents types de croisements.

\begin{tabular}{|c|c|c|c|c|c|c|c|c|}
\hline \multirow{3}{*}{$\begin{array}{c}\text { Chromosome } \\
\text { pair }\end{array}$} & \multirow{3}{*}{$\begin{array}{c}\text { Type } \\
\text { of mating }\end{array}$} & \multicolumn{6}{|c|}{$\begin{array}{l}\text { Chromosome variants in progeny } \\
\text { (number of arimals) }\end{array}$} & \multirow{3}{*}{$\begin{array}{c}\text { Chi-square } \\
\text { test }\end{array}$} \\
\hline & & \multicolumn{3}{|c|}{ Observed } & \multicolumn{3}{|c|}{ Expected } & \\
\hline & & ++ & +-1 & - & ++ & +-1 & - & \\
\hline 16 & $\begin{array}{l}+-\times+- \\
+-\times--\end{array}$ & $\begin{array}{l}3 \\
-\end{array}$ & $\begin{array}{l}10 \\
13\end{array}$ & $\begin{array}{r}3 \\
11\end{array}$ & $\begin{array}{l}4 \\
-\end{array}$ & $\begin{array}{r}8 \\
12\end{array}$ & $\begin{array}{r}4 \\
12\end{array}$ & $\begin{array}{l}\text { N.S. }(1.0) \\
\text { N.S. }(0.17)\end{array}$ \\
\hline 17 & $\begin{array}{l}+-\times+- \\
+-\times--\end{array}$ & $\begin{array}{l}5 \\
-\end{array}$ & $\begin{array}{l}13 \\
18\end{array}$ & $\begin{array}{c}3 \\
24\end{array}$ & $\begin{array}{l}5.25 \\
-\end{array}$ & $\begin{array}{l}10.5 \\
21\end{array}$ & $\begin{array}{l}5.25 \\
21\end{array}$ & $\begin{array}{l}\text { N.S. }(1.57) \\
\text { N.S. }(0.86)\end{array}$ \\
\hline 18 & $+-\times--$ & 一 & 4 & 3 & - & 3.5 & 3.5 & N.S. $(0.01)$ \\
\hline
\end{tabular}

N.S. : non significant at $\mathrm{P}<0.01$. 
Inheritance investigations are presented in two tables (tabl. 1 and 2). In table 1, all studied families are shown with reference to the $\mathrm{C}$-band variants. In all families, the variants in the progeny occurred in agreements with the Mendelian law, as confirmed by the chi-square test (tabl. 2). The test was used for each chromosome pair separately. As it is shown, there are no significant differences between the observed and expected numbers of individuals in the progeny. Among the studied families we found one (No. 5, tabl. 1) deviant distribution of variants in pair 17. Of the two variants expected among the progeny $(+-)$ and $(--)$ nine cases of $(--)$ were observed but only one of $(+-)$.

\section{Discussion}

Among several papers concerning $\mathrm{C}$-band variants in swine, only three investigators described this phenomenon applying sequential $Q$ and $C$ stainings (Fries \& Stranzinger, 1981; Hansen, 1981, 1982). In the present paper, identification of the chromosomes was made according to sequential staining of material from a representative family.

The observed variability in the size of the C-band in telocentric chromosomes can be divided into two categories. The chromosome pairs 16, 17, and 18 belong to the first category. In these pairs we found very clear and easily recognisable $\mathrm{C}$-band variants and since they follow the Mendelian law (tabl. 1 and 2) we are able to define this polymorphism. The second group consisted of pairs 13 and 15 . In these pairs variants seemed to be clear, but because of smaller differences in the size of the C-band between the variants in some animals their definition was less clear-cut. For this reason only pairs 16, 17 and 18 were considered in the inheritance study which demonstrated, in agreement with the literature on other species, that these variants are inherited according to the Mendelian principle. However, we found one family (No. 5) with deviant inheritance of $\mathrm{C}$-band variants in pair 17 . This exceptional event can be explained by a chance occurrence of such a distribution among the progeny, due to the small number of animals within this family and perhaps to selection disadvantage caused by other factors involved. Moreover, the chi-square tests for all studied families (table 2) did not show any significant differences between observed and expected numbers of animals in progeny of different types of mating. In a few families two or three polymorphic chromosome pairs were observed; this could be a chance occurrence, but with such limited data we cannot exclude the possibility that inheritance of two or three variants could in some way be related.

As a conclusion one can state that the stability of C-band variants within animals and their hereditary character establishes the observed variability as a polymorphism, and permits the use of $\mathrm{C}$-band variant chromosomes as marker chromosomes. Such marker chromosomes can be used, for example, in gene mapping studies in swine using family investigations (FRIES et al., 1982 and FrIES, 1982), as it was applied in human genetics, and for laboratory animals. In pairs 13 and 15 the situation is not very clear because of smaller differences of size of the C-bands, but with more accurate measurement it may be possible to define distinct variants in the future.

It is important to establish whether the observed variability in the size of the C-bands is caused by genetic factors only or is influenced strongly by the technical 
procedures of C-band methods as indicated by HANSEN (1981 and 1982). From our findings we can say that such technical factors assume importance only when studying small size differences between $\mathrm{C}$-bands variants such as in chromosomes pairs 13 and 15 , or when analyzing a small number of metaphases per animal. Thus technical problems could have contributed in some instances to the difficulties we experienced in studying chromosome pairs 13 and 15. On the other hand, the influence of technical factors appears to be negligible with regard to the large differences in C-band variants which characterize, e.g., chromosome pairs 16, 17 and 18. Moreover, by applying sequential staining with DA-DAPI and C-banding it can be shown that the C-band variants correspond exactly to the DA-DAPI (FRIES, 1982). Inheritance studies of C-band variants were already done by Christensen \& SMEDEgard (1978, 1979) for pairs 16 and 15 , respectively, but unfortunately without preidentification with the Q-band method.

Hence, the phenomenon of C-band polymorphism is important for animal breeding and experimental cytogenetics, and further applications might arise, for instance in a gene mapping study.

\section{Received October 12, 1982.}

Accepted June 13, 1893.

\section{Acknowledgements}

We like to thank Miss Irène KeEman and Mr. M. Lauber for technical assistance, and the Swiss Association for Artificial Insemination and the farmers who provided information and blood samples.

\section{References}

AtKin N.B., Brito-Babpulle V., 1981. Heterochromatin polymorphism and human cancer. Cancer Genet. Cytogenet., 3, 261-272.

Caspersson T., Zech L., Modest E.J., Foley G.E., Wagh U., Simonsson E., 1969. DNA-binding fluorochromes for the study of the organization of the metaphase nucleus. Exp. Cell Res., 58, 141-152.

Christensen K., Smedegird K., 1978. Chromosome marker in domestic pigs, C-band polymorphism. Hereditas, 88, 269-272.

Christensen K., Smedegåd K., 1979. Chromosome markers in domestic pigs : A new C-band polymorphism. Hereditas, 90, 303-304.

Craig-Holmes A.P., Moore F.B., Shaw M.W., 1975. Polymorphism of human C-band heterochromatin : II family studies with suggestive evidence for somatic crossing over. Am. J. Hum. Genet., 27, 178-189.

Dev V.G., Miller D.A., Miller O.J., 1973. Chromosome markers in Mus musculus : strain differences in C-banding. Genetics, 75, 663-670.

Di Berardino D., Iannuzzi L., Di Meo G.P., Zacchi R., 1980. Constitutive heterochromatin polymorphism in chromosomes of cattle (Bos taurus). Proceedings of the IV European Colloquium on Cytogenetics of Domestic Animals, Uppsala, June 10-13, 1980, 438-457. 
Fries R., STRANZinger G., 1981. Identification of C-band-polymorphisms in swine by a sequential Q- C-banding technique. Proceedings of the IV European Chromosome Analysis Workshop, Edinburgh.

Fries R., Stranzinger G., 1982. Chromosomal mutations in pigs derived from X-irradiated semen Cytogenet. Cell Genet., 34, 55-66.

Fries R., Stranzinger G., Vögeli P.. 1982. Relationships of immunogenetic and biochemical markers to natura! and induced chromosomal variarts in swine, Abstract of the $V$ European Colloquium on Cytogenetics of Domestic Animals, Milano-Gargnano, June 7-11, 1982, 225-233.

FrIES R., 1982. Natürliche und induzierte Markerchromosomen beim Schwein und ihre Verwendung in der Genkartierung. Doctor's dissertation, ETH, Zürich.

Glahn-Luft B., Wassmuth R., Dzapo V., 1981. C-Band Polymorphismus beim Schwein. Vortragstagung der Gesellschaft für Tierzuchtwissenschaft und der Deutschen Gesellschaft für Züchtungskunde, Giessen.

Glahn-Luft B., Dzapo V., Wassmuth R., 1982. Polymorphism of C-banding in swine. Abstract of the $V$ European Colloquium on Cytogenetics of Domestic Animals, MilanoGargnano, June 7-11, 1982, 312-317.

Hansen-Melander E., Melander Y., 1974. The karyotype of the pig. Hereditas, 77, 149-158.

HANSEN K.M., 1981. C-band polymorphism in pig chromosomes, facts or technical errors. J. Anim. Sci., 53, Supplement 1, 161.

HANSEN K.M., 1982. Sequential Q- and C-band staining of pig chromosomes, and some comments on C-band polymorphism and C-band technique. Hereditas, 96, 183-189.

Jacobs P.A., Frackiewicz A., Law P., Hilditch J., Morton N.E., 1975. The effect of structural aberrations of the chromosomes on reproductive fitness in man II. Result. Clin. Genet., 8, 169-178.

Lin C.C., Joyce E., Biederman B.M., Gerhart S., 1982. The constitutive heterochromatin of porcine chromosomes. J. Hered., 73, 231-233.

Mäkinen A., Gustavsson I., 1980. Centric fusion polymorphism and size heteromorphism in the karyotype of the blue fox (Alopex lagopus). Proc. IV European Colloquium on Cytogenetics of Domestic Animals, Uppsala, June 10-13, 1980, 398-405.

Phillips R.B., 1977. Inheritance of $\mathrm{Q}$ and C-band polymorphisms. Can. J. Genet. Cytol., 19, 405-413.

Popescu C.P., Boscher J., 1974. Etude du caryotype bovin par une nouvelle méthode cytogénétique : les bandes C. 1st World Congress on Genetics Applied to Liverstock Production, Madrid, October 7-11, 1974, Symposia, 3, 159-164.

Reading Conference, 1976. Proceedings of the 1st International Conference for Standardisation of Banded Karyotypes of Domestic Animals, edited by Ford C.E., Pollock D.L., Gustavsson I. Hereditas, 92, 145-162.

Robinson J.A., Buckton K.E., Spowart G., Newton M., Jacobs P.A., Evans H.J., HILL R., 1976. The segregation of human chromosome polymorphisms. Ann. Hum. Genet., 40, 113-121.

Robson M.K., Anderson J.M., Garson O.M., Matthews J.P., Sandeman T.F., 1981. Constitutive heterochromatin (C-banding) studies in patients with testicular malignancies. Cancer Genet. Cytogenet., 4, 319-323.

Soudek D., Sroka H., 1979. Chromosomal variants in mentally retarded and normal men. Clin. Genet., 16, 109-116.

SUMNER A.T., 1972. A simple technique for demonstrating centromeric heterochromatin. Exp. Cell Res., 75, 304-306.

SYSA P.S., 1980. Polymorphism of metaphase chromosomes in swine (Sud scrofa L.). Genet. Vol., 52/53, 312-315.

Świtoński M., Stranzinger G., Fries R., 1982. C-band polymorphism in rabbit (Oryctolagus cuniculus). Submitted to Z. Tierz. Züchtungsbiol.

Yosida T.H., SAgai T., 1975. Variation of C-bands in the chromosomes of several subspecies of Rattus rattus. Chromosoma, 50, 283-300. 